\title{
Uji Kinerja Alat Penjerap Warna dan pH Air Gambut Menggunakan Arang Aktif Tempurung Kelapa \\ Suhendraa*, Winda Apriania ${ }^{a}$ Ellys Mei Sundaria \\ aJurusan Teknik Mesin, Politeknik Negeri Sambas \\ Jalan Raya Sejangkung, Sambas, Indonesia \\ * Email : aka.suhendra@yahoo.com
}

\begin{abstract}
Abstrak
Penelitian ini bertujuan untuk melakukan uji kinerja alat penjerap warna dan $\mathrm{pH}$ air gambut serta membuktikan lama waktu air mengalir dari kolom penjerap terhadap perubahan warna dan $\mathrm{pH}$ air gambut. Air gambut sebagai bahan uji berasal dari 3 lokasi yang berbeda. Pengukuran dilakukan saat air gambut mengalir keluar dari kolom penjerap pada menit ke 0, 10, 30, 60 dan 120 menit. Uji kinerja alat penjerap warna dan $\mathrm{pH}$ air gambut menghasilkan rata-rata debit aliran air sebesar $1.340 \mathrm{~mL} / \mathrm{menit}$, waktu kontak air dengan karbon aktif pada kolom penjerap sekitar 65 detik. Berdasarkan hasil pengujian, alat ini terbukti dapat melakukan penjerapan warna dan meningkatkan nilai $\mathrm{pH}$ air gambut. Kolom penjerap efektif digunakan untuk menjerap warna selama sekitar 60 menit atau dapat digunakan pada air gambut sebanyak 80, 4 Liter, serta dapat digunakan selama 120 menit untuk meningkatkan nilai pH air gambut atau dapat digunakan pada air gambut sebanyak 160,8 liter. Hasil uji kinerja alat penjerap warna dan $\mathrm{pH}$ air gambut menunjukkan bahwa penjerapan warna dan kenaikan pH terbaik diperoleh pada perlakuan T1 yaitu waktu aliran air keluar dari kolom penjerap pada 0 menit. Sampel A mengalami penurunan kadar warna dari 414 Pt-Co. menjadi 244 Pt-Co., dengan penjerapan warna 41,06\%, sedangkan nilai pH mengalami kenaikan sebesar 1,26. Sampel B mengalami penurunan kadar warna dari 667 Pt-Co. menjadi 474 Pt-Co., dengan penjerapan warna 28,94\%, sedangkan nilai pH mengalami kenaikan sebesar 1,55. Sampel C mengalami penurunan kadar warna dari 1537 Pt-Co. menjadi 1084 PtCo., dengan penjerapan warna 29,47\%, sedangkan nilai pH mengalami kenaikan sebesar 1,23.
\end{abstract}

\section{Kata Kunci : Air gambut, pH air, warna air}

\section{Latar Belakang}

Pelayanan air bersih di Kabupaten Sambas masih menghadapi kendala dalam pengadaan air bersih. Permasalahan yang dihadapi adalah masih rendahnya cakupan pelayanan diakibatkan kurangnya debit air yang dihasilkan serta masih belum terpenuhinya standar air bersih yang didistribusikan karena kurangnya sistem pengolahan. Dengan demikian sebagian besar masyarakat masih memanfaatkan air sistem non perpipaan seperti sumur, sungai, mata air serta air hujan.

Salah satu air sistem non perpipaan yang banyak dimanfaatkan masyarakat di Kota Sambas adalah air sumur dan sungai. Pemenuhan kebutuhan air dengan sumber air sumur dan sungai ini semakin meningkat dengan meningkatnya jumlah perumahan di Kota Sambas, sementara cakupan layanan PDAM belum dapat memenuhi kebutuhan tersebut.

Secara fisik air sumur dan sungai di Kota Sambas terlihat berwarna kuning terang, coklat atau merah kehitaman dengan kadar $\mathrm{pH}$ rendah. Warna dan pH air sumur Kota Sambas ini melebihi kadar maksimum kualitas air bersih yang diperbolehkan sesuai dengan ketentuan [6] tentang syarat-syarat dan pengawasan kualitas air. Berdasarkan Permenkes No. 416, parameter warna air bersih maksimum yang diizinkan adalah 15 TCU dan tidak berasa.

Air sumur, rawa, atau sungai yang terasa bau dan berwarna kuning dapat diolah melalui pengolahan adsorpsi [2]. Media yang dapat digunakan dalam pengolahan air secara adsorpsi adalah karbon aktif atau arang yang terbuat dari apa saja yang dapat dibuat arang aktif. Karbon aktif merupakan media yang sangat efektif dalam penyerapan zat terlarut dalam air, baik organik maupun anorganik.

Metode penjernihan sederhana yang secara umum dikenal masyarakat Kota Sambas yaitu menggunakan tawas dan pasir. Metode ini belum mampu menurunkan kadar warna air sumur. Apabila setelah melewati saringan pasir cepat air masih berwarna, berbau dan mengandung bahan organik, maka untuk menghilangkan bahan tersebut, dapat dilakukan proses penjerapan (adsorpsi) misalnya dengan melewatkan air melalui kolom yang berisi karbon aktif (activated carbon) atau yang biasa disebut arang aktif [5]. 
Penelitian yang dilakukan [3] menunjukkan adanya penurunan kadar warna air sungai dari 92 TCU menjadi 19 TCU melalui proses adsorpsi menggunakan arang aktif sekam kulit kopi. Penurunan kadar warna ini disebabakan terbukanya pori-pori sekam kulit kopi yang telah diaktifkan, sehingga terjadi proses adsorpsi. Selain itu, dalam pengolahan air, arang aktif digunakan sebagai adsorben untuk menyisihkan rasa, bau atau warna yang disebabkan oleh kandungan bahan organik dalam air, produk samping disinfeksi, pestisida, dan bahan organik sintetis lainnya [4].

Penelitian dilakukan [1] dengan metode penjerapan warna air sungai Sambas menggunakan arang aktif. Hasil penelitian menunjukkan bahwa arang aktif mampu menurunkan kadar warna air sungai Sambas yang merupakan air gambut dengan ciri-ciri warna air kuning terang dengan kekeruhan rendah dan $\mathrm{pH}$ rendah.

Adsorpsi atau biasa disebut peristiwa penjerapan, didefinisikan sebagai suatu proses yang terjadi ketika suatu fluida (cairan maupun gas) terikat pada suatu padatan dan akhirnya membentuk suatu film (lapisan tipis) pada permukaan padatan tersebut. Komponen yang terjerap disebut adsorbat dan bahan yang dapat menjerap disebut adsorben. Adsorben dapat berupa padatan atau cairan. Adsorbat terlarut dalam cairan atau berada dalam gas. Dalam penelitian ini arang aktif berperan sebagai adsorben, zat warna sebagai adsorbat dan air sumur sebagai pelarutnya.

Tujuan penelitian ini adalah untuk melakukan uji kinerja alat penjerap warna dan $\mathrm{pH}$ air dalam menurunkan tingkat warna dan meningkatkan $\mathrm{pH}$ air gambut serta menentukan hubungan antara lama waktu air mengalir dari kolom penjerap terhadap perubahan warna dan $\mathrm{pH}$ air gambut. Hasil penelitian ini diharapkan dapat dijadikan sebagai referensi dalam pembuatan alat pengolah air gambut dengan arang aktif tempurung kelapa sebagai media penjerap warna dan $\mathrm{pH}$.

\section{Metodologi}

Tahap pelaksanaan penelitian ini meliputi tahap rancang bangun, pengujian dan analisis data. Rancang bangun alat penjerap warna dan $\mathrm{pH}$ air gambut dilakukan di bengkel pemesinan Jurusan Teknik Mesin Politeknik Negeri Sambas.
Desain alat penjerap warna dan $\mathrm{pH}$ air gambut dapat dilihat pada gambar 1. Aliran proses penjerapan dimulai dari air gambut yang dipompa menuju bak air awal yang berupa tandon kapasitas 250 Liter. Kolom kontrol merupakan kolom yang terbuat dari wadah berbentuk persegi yang dilengkapi pelampung untuk mengontrol tinggi muka air sebelum masuk menuju kolom penjerap.

Kolom penjerap pada alat ini dirancang dengan model pipa annulus dengan arah aliran mengikuti annulus. Pipa bagian luar merupakan pipa yang berisi arang aktif dan pipa bagian dalam merupakan pipa tempat aliran air masuk. Kolom ini akan diisi dengan arang aktif. Kebutuhan arang aktif pada proses penjerapan ini sesuai kapasitas kolom penjerap. Kolom isian arang aktif ini merupakan kolom pipa bagian luar. Pipa bagian luar dirancang dengan dengan diameter $2 \frac{1}{2}$ inch dan tinggi $50 \mathrm{~cm}$. Kolom pipa bagian dalam tempat aliran air masuk dirancang dengan dengan diameter 1 inch dan tinggi 46 $\mathrm{cm}$.

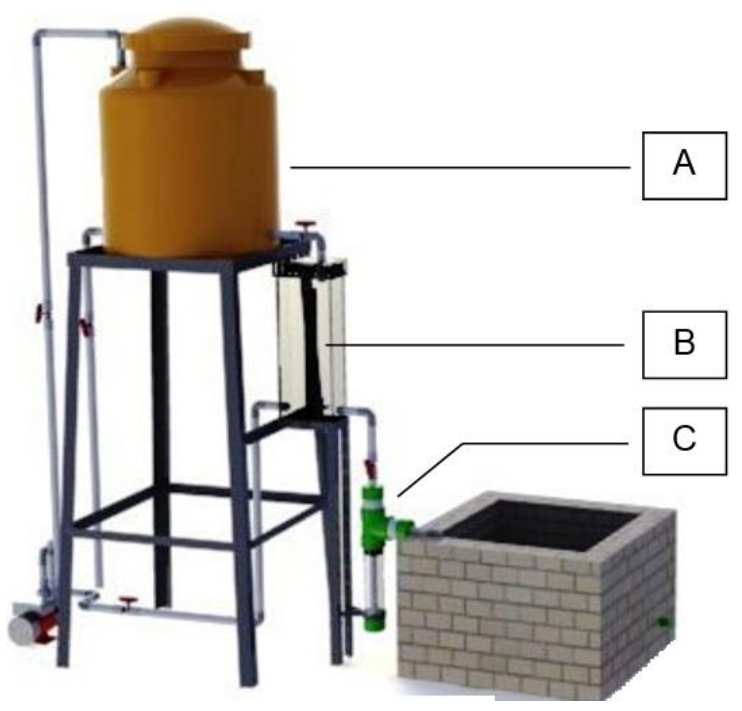

Gambar 1. Desain alat penjerap warna dan $\mathrm{pH}$ air gambut

Keterangan :

(A) Tandon air

(B) Kolom kontrol level

(C) Kolom penjerap

Arah aliran air dalam kolom penjerap pada proses penjerapan ini dapat dilihat pada Gambar 2. Aliran mengikuti annulus dengan arah aliran dari atas ke bawah pada pipa bagian dalam dan menuju ke atas pada pipa bagian luar (pipa arang aktif) sehingga memenuhi pipa arang aktif tersebut. Arah aliran tersebut untuk memaksimalkan kontak antara arang aktif dan air sumur. 
Alat yang digunakan dalam penelitian ini adalah timbangan, saringan, wadah plastik, stopwatch, gelas ukur $1000 \mathrm{~mL}$, botol plastik, corong kaca. Bahan uji dalam penelitian ini adalah air gambut yang diambil dari 3 lokasi yang berbeda di kota Sambas, yaitu di Desa Dalam Kaum, Desa Lubuk Dagang dan Desa Kartiasa. Ketiga Desa tersebut masih berada dalam wilayah Kecamatan Sambas.

\section{Aliran masuk dari kolom kontrol}

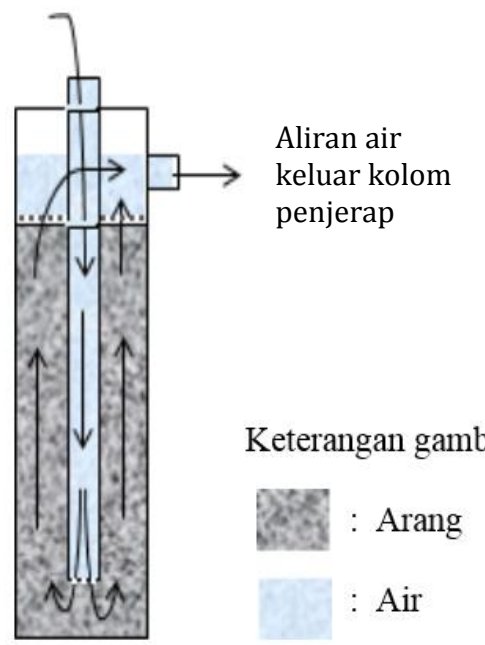

Gambar 2. Arah aliran air pada kolom penjerap

Prosedur pengujian dilakukan dengan menentukan terlebih dahulu variabel yang digunakan dalam penelitian, selanjutnya dilakukan pengujian alat penjerap warna dan $\mathrm{pH}$ air gambut dengan 3 kali pengulangan. Variabel bebas penelitian adalah jenis air gambut yang diambil dari tiga lokasi dan waktu aliran air keluar dari kolom penjerap yang divariasikan menjadi lima perlakuan yaitu 0, 10, 30, 60 dan 120 menit. Variabel tak bebas penelitian adalah parameter warna dan $\mathrm{pH}$ air gambut setelah melalui proses penjerapan.

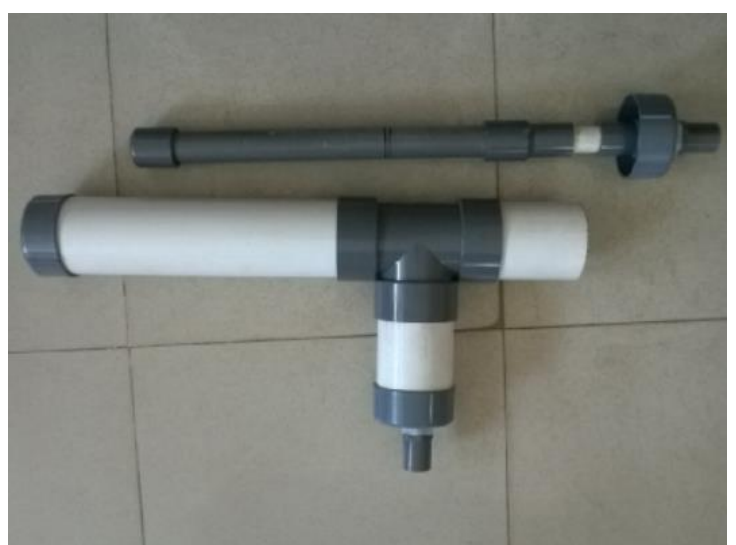

Gambar 3. Bentuk kolom penjerap
Warna dari larutan contoh uji ditentukan secara spektrofotometri pada panjang gelombang $450 \mathrm{~nm}$ - $465 \mathrm{~nm}$ menggunakan larutan standar Pt-Co. Pengukuran nilai warna sebenarnya (true color) berdasarkan hukum Beers [7]. Kemampuan arang aktif untuk menurunkan warna air dianalisis dengan persen penjerapan. Persen penjerapan dihitung dengan persamaan berikut :

$$
\% \text { Penjerapan }(\%)=\frac{\mathrm{Co}-\mathrm{Ce}}{\mathrm{Co}} \times 100 \%
$$

Keterangan :

Co $=$ Konsentrasi awal warna (Pt.co)

$\mathrm{Ce}=$ Konsentrasi akhir warna (Pt.co)

Analisis pengukuran $\mathrm{pH}$ air gambut dilakukan dengan mengukur $\mathrm{pH}$ air gambut sebelum memasuki alat penjerap air kemudian dibandingkan dengan $\mathrm{pH}$ air setelah keluar dari alat penjerap air.

\section{Hasil dan Pembahasan}

Alat penjerap warna dan $\mathrm{pH}$ air gambut dibuat dengan tahapan pembuatan rangka alat, kolom penjerap, wadah kontrol level air dan instalasi alat. Pengukuran kadar $\mathrm{pH}$ air gambut menggunakan $\mathrm{pH}$ meter. Pengukuran warna air dilakukan di Badan Penelitian dan Pengembangan Industri, Balai Riset dan Standarisasi Industri Pontianak.

Uji kinerja alat penjerap warna dan pH air gambut menghasilkan rata-rata debit aliran air sebesar $1.340 \mathrm{~mL} /$ menit, waktu kontak air dengan karbon aktif dalam kolom penjerap sekitar 65 detik dengan jumlah karbon aktif yang digunakan dalam satu kali pengujian adalah sebanyak $800 \mathrm{~cm}^{3}$.

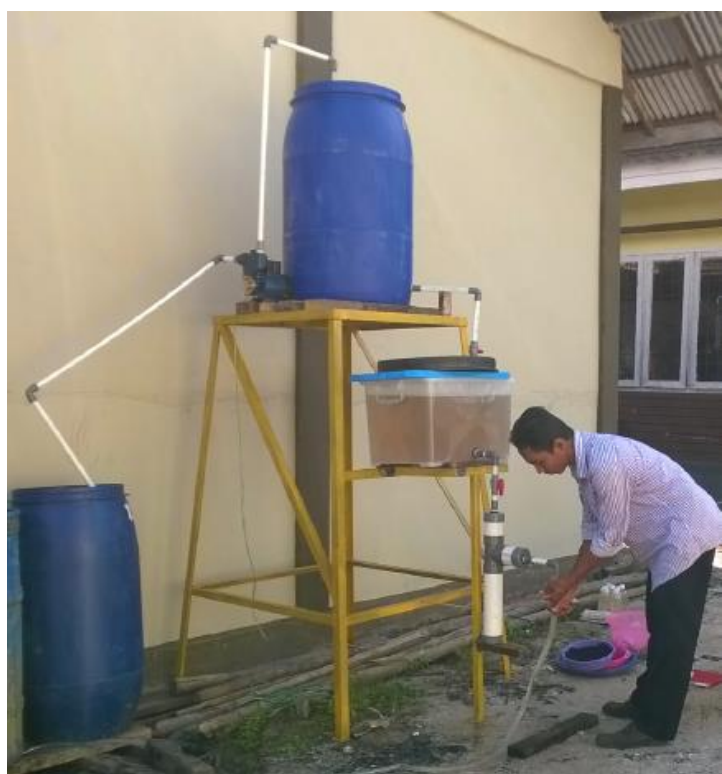

Gambar 4. Uji kinerja alat penjerap warna dan $\mathrm{pH}$ air gambut 
Hasil uji statistik (anova) menunjukkan bahwa lamanya waktu air keluar dari kolom penjerap memiliki pengaruh yang sangat signifikan terhadap persen penjerapan warna air gambut. Terlihat bahwa air gambut yang mengalir keluar pertama kali (T1) dari kolom penjerap memiliki tingkat persen penjerapan warna tertinggi. Hal ini dapat dilihat dari ketiga sampel uji air yang menunjukkan persen penjerapan berkisar antara 41,06 \% sampai dengan $28,94 \%$.

Tabel 1. Hasil pengujian nilai persentase penjerapan warna

\begin{tabular}{llll}
\hline & \multicolumn{3}{c}{ Persen Penjerapan } \\
\cline { 2 - 4 } & A & B & C \\
\hline T0 & $0 \%$ & $0 \%$ & $0 \%$ \\
T1 & $41,06 \%$ & $28,94 \%$ & $29,47 \%$ \\
T2 & $36,71 \%$ & $13,64 \%$ & $12,69 \%$ \\
T3 & $24,15 \%$ & $15,89 \%$ & $8,52 \%$ \\
T4 & $1,21 \%$ & $7,65 \%$ & $-14,05 \%$ \\
T5 & $-0,48 \%$ & $-0,30 \%$ & $-6,64 \%$ \\
\hline
\end{tabular}

Keterangan :

T0 : Air gambut tanpa perlakuan

T1 : Waktu aliran air keluar 0 menit

T2 : Waktu aliran air keluar 10 menit

T3 : Waktu aliran air keluar 30 menit

T4 : Waktu aliran air keluar 60 menit

T5 : Waktu aliran air keluar 120 menit

A : Sampel air dari Desa Dalam Kaum

B : Sampel air dari Desa Lubuk Dagang

C : Sampel air dari Desa Kartiasa

Bertambahnya waktu aliran air keluar dari kolom penjerap menyebabkan persen penjerapan warna air gambut oleh karbon aktif semakin berkurang. Pengujian dengan waktu aliran air keluar dari kolom penjerap mencapai 60 menit, menunjukkan bahwa warna air gambut hampir tidak mengalami perubahan. Hal ini membuktikan bahwa semakin lama waktu kontak antara air gambut dengan karbon aktif maka kemampuan karbon aktif untuk menjerap warna air akan semakin berkurang.

Kolom penjerap yang dibuat hanya efektif digunakan untuk menjerap warna air gambut selama sekitar 60 menit atau efektif digunakan untuk menjerap air sebanyak 80,4 liter. Penggunaan kolom penjerap lebih dari 60 menit masih dapat dilakukan, namun kemampuan karbon aktif untuk menjerap warna sudah sangat lemah. Hasil pengujian dengan waktu aliran air keluar dari kolom penjerap selaman 120 menit, menunjukkan bahwa warna air sudah sama dengan air yang tidak diuji.
Kemampuan karbon aktif untuk menjerap warna juga dipengaruhi oleh faktor warna air gambut itu sendiri. Sampel uji gambut yang diperoleh dari Desa Kartiasa (sampel C) merupakan air gambut dengan warna yang paling gelap dibanding sampel air gambut lainnya, dengan warna mencapai 1.753 Pt-Co. Dari data dapat dilihat bahwa air gambut sampel C memiliki rata-rata persen penjerapan warna paling rendah dibanding sampel lainnya. Selain itu, dari gambar 4 dapat dilihat bahwa air gambut sampel $\mathrm{C}$ juga mengalami penurunan penjerapan warna yang paling cepat, dimana dalam waktu kurang dari 60 menit karbon aktif sudah tidak mampu lagi melakukan penjerapan warna pada air gambut sampel C.

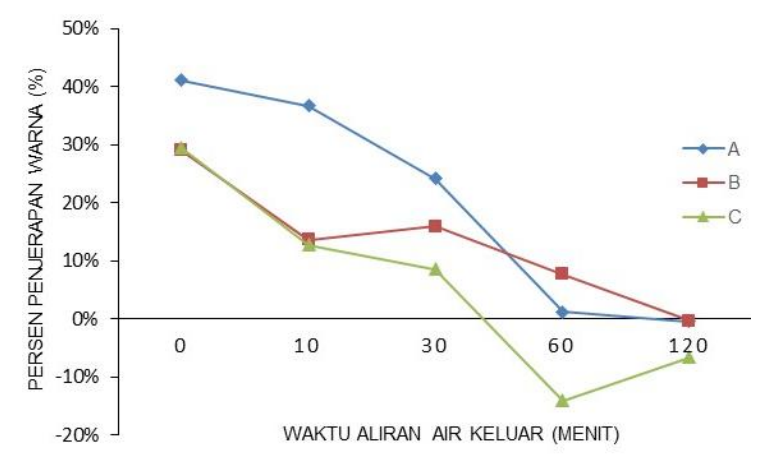

Gambar 5. Hubungan antara waktu aliran air keluar terhadap persen penjerapan warna

Kemampuan arang aktif tempurung kelapa untuk meningkatkan nilai $\mathrm{pH}$ sampel uji diketahui dengan melakukan pengukuran langsung menggunakan $\mathrm{pH}$ meter. Rata-rata kenaikan $\mathrm{pH}$ hasil pengujian dapat dilihat pada tabel 2.

Tabel 2. Hasil pengujian kenaikan $\mathrm{pH}$ air gambut

\begin{tabular}{llll}
\hline & \multicolumn{3}{c}{ Kenaikan $\mathrm{pH}$} \\
\cline { 2 - 4 } & $\mathrm{A}$ & $\mathrm{B}$ & $\mathrm{C}$ \\
\hline T0 & 4,30 & 4,46 & 4,15 \\
T1 & 5,56 & 6,01 & 5,38 \\
T2 & 5,01 & 5,69 & 5,19 \\
T3 & 4,50 & 5,50 & 4,99 \\
T4 & 4,26 & 5,01 & 4,54 \\
T5 & 4,13 & 4,54 & 4,10 \\
\hline
\end{tabular}

Hasil uji statistik (anova) menunjukkan bahwa lamanya waktu air keluar dari kolom penjerap memiliki pengaruh yang sangat signifikan terhadap kenaikan $\mathrm{pH}$ air gambut. Hasil pengujian menunjukkan bahwa air yang pertama keluar dari kolom penjerap (T1) mengalami kenaikan nilai $\mathrm{pH}$ yang paling tinggi. Air gambut sampel B merupakan air gambut yang paling tinggi mengalami kenaikan nilai $\mathrm{pH}$ yaitu sebesar 1,55. Dari ketiga sampel uji, rata- 
rata kenaikan nilai $\mathrm{pH}$ pada perlakuan $\mathrm{T} 1$ sebesar 1,34. Hal ini menunjukkan bahwa pada perlakuan tersebut karbon aktif memiliki kemampuan untuk meningkatkan $\mathrm{pH}$ air gambut. Dengan semakin banyaknya air gambut yang melewati karbon pada kolom penjerap menyebabkan kemampuan karbon untuk menaikkan nilai pH air semakin berkurang. Hal tersebut dapat dilihat pada gambar 5 dimana grafik menunjukkan penurunan nilai $\mathrm{pH}$ dengan semakin lamanya waktu air keluar dari kolom penjerap.

Kolom penjerap yang dibuat hanya dapat digunakan selama tidak lebih dari 120 menit untuk menaikkan nilai $\mathrm{pH}$ air. Hal ini terlihat dari hasil pengujian dengan waktu aliran air keluar dari kolom penjerap selama 120 menit (T5), dimana nilai pH air sudah setara dengan air tanpa perlakuan. Dengan demikian, kolom penjerap hanya efektif digunakan untuk menaikkan nilai $\mathrm{pH}$ air gambut dengan volume tidak lebih dari 160,8 liter.

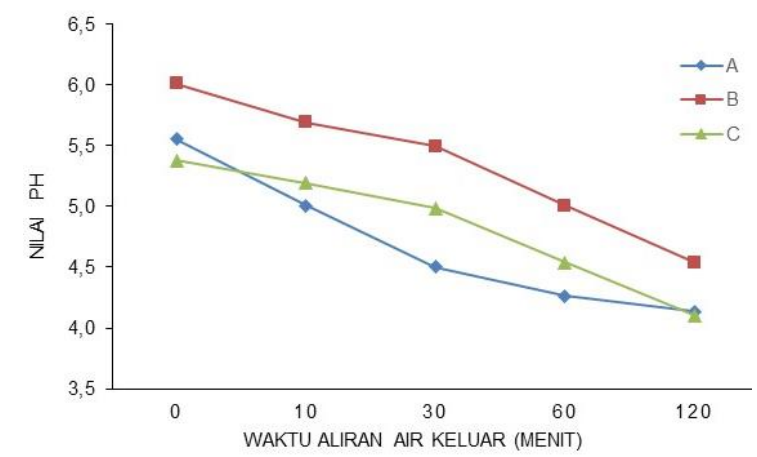

Gambar 6. Hubungan antara waktu aliran air keluar terhadap nilai $\mathrm{pH}$ air

Nilai perubahan penjerapan warna dan kenaikan $\mathrm{pH}$ air gambut sangat tergantung pada jumlah dan jenis karbon aktif yang digunakan. Pada penelitian ini karbon aktif yang digunakan merupakan karbon aktif komersil yang dibeli langsung dari toko. Jumlah karbon aktif yang digunakan dalam sekali uji sampel adalah sebanyak $800 \mathrm{~cm}^{3}$. Berdasarkan hasil pengujian terbukti bahwa karbon aktif dapat digunakan untuk menjerap warna dan meningkatkan $\mathrm{pH}$ air gambut. Kemampuan karbon untuk menjerap warna dan meningkatkan $\mathrm{pH}$ air gambut akan semakin berkurang dengan semakin lamanya waktu kontak karbon aktif dan air gambut.

\section{Kesimpulan}

Berdasarkan hasil pengujian alat penjerap warna dan $\mathrm{pH}$ air gambut menggunakan arang aktif tempurung kelapa terbukti dapat melakukan penjerapan warna dan dapat meningkatkan nilai $\mathrm{pH}$ air gambut.

Hasil uji kinerja alat penjerap warna dan $\mathrm{pH}$ air gambut menunjukkan bahwa penjerapan warna dan kenaikan pH terbaik diperoleh pada perlakuan T1 yaitu waktu aliran air keluar dari kolom penjerap pada 0 menit. Sampel A mengalami penurunan kadar warna dari 414 PtCo. menjadi 244 Pt-Co., dengan penjerapan warna 41,06\%, sedangkan nilai $\mathrm{pH}$ mengalami kenaikan sebesar 1,26. Sampel B mengalami penurunan kadar warna dari 667 Pt-Co. menjadi 474 Pt-Co., dengan penjerapan warna 28,94\%, sedangkan nilai $\mathrm{pH}$ mengalami kenaikan sebesar 1,55. Sampel C mengalami penurunan kadar warna dari 1537 Pt-Co. menjadi 1084 Pt-Co., dengan penjerapan warna 29,47\%, sedangkan nilai pH mengalami kenaikan sebesar 1,23.

\section{Daftar Pustaka}

[1] Apriani, W., 2013, Pengaruh Jenis Arang Aktif Ampas Tebu, Tatal Kayu dan Tempurung Kelapa Terhadap Kemampuan Penjerapan Warna Air Sungai Sambas, Tesis, Magister Sistem Teknik, UGM, Yogyakarta

[2] Kusnaedi, 2010, Mengolah Air Kotor Untuk Air Minum, Penebar Swadaya, Jakarta

[3] Mardiningsih, D., 2004, Kemampuan Arang Aktif Sekam Kulit Kopi Dalam Penurunan Kadar Air Sungai Way Kuripan Bandar Lampung, Skripsi, Undip, Semarang

[4] Masduqi, 2010, Bagian II : Proses Pengolahan Secara Fisik

[5] Nizam, 2003, Bahan Kuliah : Kebutuhan Air, Magister Pengelolaan Sumberdaya Air, Fakultas Teknik Sipil, UGM, Yogykarta

[6] Peraturan Menteri Kesehatan R.I No : 416/MENKES/PER/IX/1990 tentang : Syarat-syarat dan Pengawasan Kualitas Air

[7] SNI 6989.80 : 2011, Air Dan Air Limbah Bagian 80 : Cara Uji Warna Secara Spektrofotometri, Badan Standardisasi Nasional 